\title{
Lymphocyte sensitization to thymus and lymph
antigen in multiple sclerosis and other neurological diseases
}

\author{
E. J. FIELD AND E. A. CASPARY \\ From the Medical Research Council Demyelinating Diseases Unit, \\ Newcastle General Hospital, Westgate Road, Newcastle upon Tyne
}

SUMMARY Circulating lymphocytes from patients with multiple sclerosis are sensitized to saline homogenate of human thymus. They also show a minor degree of sensitization to lymph node extract. The sensitization to thymus is greater in multiple sclerosis than it is in other neurological $\vec{\omega}$ disease (except dementia paralytica) and this may be related to the degree of parenchymatous destruction which provides the antigen stimulus or to astroglial overgrowth in these diseases. The observations support the view that human brain and thymus may share antigen(s) of the type $\dot{c}_{0}$ known as $\phi$-antigen in mice.

In a study of cellular sensitization in myasthenia gravis, patients with multiple sclerosis were included as controls. Among the antigens tested was an extract of human thymus gland. Lymphocytes from multiple sclerosis (MS) patients but not those of other neurological diseases (OND) -with certain exceptions-were found to be especially sensitized to thymus and to a lesser extent to lymph node extracts. The special sensitization to thymus may be related to the degree of gliosis.

\section{METHODS}

Lymphocytes from 15 patients with multiple sclerosis (MS) - seven in an acute phase and eight quiescenthave been tested; 19 from other neurological diseases (OND); seven normal subjects; and 67 from patients with enlargement of the prostate gland (10 malignant) - the last group as part of a different study. Patients were not matched for age or sex. There were 11 female MS patients (aged 21-51 years) and four males (24-61 years). OND patients comprised three females (aged 26-71 years) and 16 males (aged 16-77 years). Normal subjects were from 27-57 years old and the group of prostatic patients ranged from 4684 years.

Lymphocyte sensitization was measured by the macrophage electrophoretic migration slowing method described by Field and Caspary (1970) and
Caspary and Field (1971). A review of the methof together with examples of its application in clinical immunology has been given by Field (1972). 雨 principle it depends upon the observation that sensitized lymphocytes will react with specific antक gen to produce a protein (Caspary, 1971; 1972) with. the property of causing normal guinea-pig macres phages to travel more slowly in an electric field. Normal macrophages are thus used as an indicator system for lymphocyte-antigen interaction. It seems probable that the macrophage slowing factor (MSF) is identical with macrophage inhibitory factor (MIF) which underlies the macrophage migration inhibition test of David, Al-Askari, Lawrence, and Thomas (1964), and Bloom and Bennett (1966).

Blood lymphocytes were prepared from $10-15 \mathrm{ml}$. venous blood by the carbonyl iron-methyl cellulose method of Coulson and Chalmers (1967) as modified by Hughes and Caspary (1970) and finally suspended in medium 199. Normal guinea-pig macrophages: were prepared by injecting sterile liquid paraffin intraperitoneally into normal guinea-pigs and washing out the cavity six to 10 days later with heparinized Hanks' balanced salt solution. After washing in $\mathrm{O}$ fresh Hanks' solution the cells were suspended in medium 199. Since a normal guinea-pig peritoneal $\frac{D}{0}$ macrophage exudate contains $10-20 \%$ lymphocytes, which may give a 'mixed lymphocyte reaction' with N human lymphocytes, the exudate was exposed to $\mathrm{N}$ $100 \mathrm{r} \gamma$ irradiation from a cobalt bomb to incapaci- N tate the guinea-pig lymphocytes, at least temporarily, 
from taking part in a two-way reaction. (The one way reaction is compensated for by the control tube).

Antigens used in this study were (1) encephalitogenic factor (EF) as isolated by Caspary and Field (1965) and capable (when mixed with Freund adjuvant) of producing experimental allergic encephalomyelitis (EAE) in guinea-pigs in doses as small as $1 \mu \mathrm{g}$; (2) $10 \%$ saline suspensions of two human thymuses and two cervical lymph nodes obtained at fresh necropsy from young adults where there was no reason to believe they would be pathologically affected. The tissues were ground in a Griffiths tube and cleaned by centrifugation at $1,000 \mathrm{rpm}$ for 10 minutes $(300 \mathrm{~g})$.

In practice $0.5 \times 10^{6}$ blood lymphocytes were mixed with $10^{7}$ macrophages contained in $3.0 \mathrm{ml}$. medium 199. This constituted the control mixture. Into experimental tubes $0 \cdot 1 \mathrm{ml} \cdot 10^{-1}$ suspension of thymus or lymph node or $33 \mu \mathrm{g} / \mathrm{ml}$. EF were put. After incubation for 90 minutes at room temperature $\left(20^{\circ} \mathrm{C}\right)$ the migration time over a fixed distance was measured for macrophages. These were readily recognized by their size and liquid paraffin content. Measurements were carried out in a Zeiss cytopherometer. Full experimental details and an original protocol in extenso have been set out by Caspary and Field (1971).

If $t_{c}=$ migration of macrophages in the control mixture; $t_{\theta}=$ migration time in experimental mixture; then in general $t_{e}>t_{c}$ and the percentage increase in time taken as the result of the presence of the antigen can be expressed as:

$$
\frac{t_{e}-t_{c}}{t_{c}} \times 100
$$

and this is a measure of lymphocyte sensitization. (All antigens are, of course, tested for absence of any direct toxic slowing effect upon macrophages.) These percentage figures are those shown in the Tables.

\section{RESULTS}

The percentage migration time change in the different groups of patients tested with thymus and lymph node antigens are set out in Table 1 . The results of statistical comparisons between the groups are given in Table 2. It can be seen that MS lymphocytes are more sensitized to thymus and lymph node antigen than are cells from either normal subjects or patients with other neurological disease, excluding dementia paralytica (GPI); from the latter they do not differ. Lymphocytes from OND are also more sensitized than normals with respect to both antigens but are less sensitized than those from GPI.
TABLE 1

PERCENTAGE MIGRATION TIME CHANGE IN DIFFERENT GROUPS OF PATIENTS

\begin{tabular}{|c|c|c|c|c|c|c|}
\hline & $n$ & $\bar{x}^{*}$ & $\sigma$ & $\begin{array}{c}\text { Age } \\
\text { range } \\
(y r)\end{array}$ & $M$ & $F$ \\
\hline \multicolumn{7}{|l|}{ MS } \\
\hline $\begin{array}{l}\text { Thymus } \\
\text { LN† } \\
\text { OND } \neq\end{array}$ & $\begin{array}{l}15 \\
15\end{array}$ & $\begin{array}{l}5 \cdot 540 \\
3 \cdot 313\end{array}$ & $\begin{array}{l}0.657 \\
0.630\end{array}$ & $21-61$ & 4 & 11 \\
\hline $\begin{array}{l}\text { Thymus } \\
\text { LN }\end{array}$ & $\begin{array}{l}11 \\
11\end{array}$ & $\begin{array}{l}3 \cdot 327 \\
2 \cdot 491\end{array}$ & $\begin{array}{l}1 \cdot 129 \\
0.632\end{array}$ & $26-71$ & 8 & 3 \\
\hline \multicolumn{7}{|l|}{ GPI } \\
\hline $\begin{array}{l}\text { Thymus } \\
\text { LN } \\
\text { Normal }\end{array}$ & $\begin{array}{l}8 \\
8\end{array}$ & $\begin{array}{l}5 \cdot 763 \\
3 \cdot 288\end{array}$ & $\begin{array}{l}1 \cdot 136 \\
0 \cdot 806\end{array}$ & \}9-73 & 8 & 0 \\
\hline $\begin{array}{l}\text { Thymus } \\
\text { LN }\end{array}$ & $\begin{array}{l}7 \\
7\end{array}$ & $\begin{array}{l}0.943 \\
0.871\end{array}$ & $\begin{array}{l}0.718 \\
0.730\end{array}$ & $26-56$ & 4 & 3 \\
\hline \multicolumn{7}{|l|}{ Benign prostatic } \\
\hline $\begin{array}{l}\text { Thymus } \\
\text { LN }\end{array}$ & $\begin{array}{l}56 \\
51\end{array}$ & $\begin{array}{l}0.718 \\
0.669\end{array}$ & $\begin{array}{l}0.781 \\
0.746\end{array}$ & \} $40-84$ & - & - \\
\hline \multicolumn{7}{|l|}{ Carc. prostate } \\
\hline $\begin{array}{l}\text { Thymus } \\
\text { LN }\end{array}$ & $\begin{array}{l}12 \\
12\end{array}$ & $\begin{array}{l}0.800 \\
0.675\end{array}$ & $\begin{array}{l}1 \cdot 029 \\
0.543\end{array}$ & \} $53-86$ & - & - \\
\hline
\end{tabular}

* Mean migration time of macrophages.

$+\mathbf{L N}=$ lymph node antigen.

$\ddagger$ OND = other neurological diseases (excluding GPI).

GPI lymphocytes themselves are more sensitized than normal lymphocytes in respect of both antigens.

When sensitization to thymus and lymph node is compared (Table 3) MS lymphocytes are more reactive against thymus than lymph node antigen and this applies also to OND and GPI. For normal lymphocytes there is no difference with the two antigens (Table 3).

The GPI group thus stands more closely related to the MS group than to the OND group (Table 3). Among the MS results, the

TABLE 2

STATISTICAL COMPARISONS BETWEEN GROUPS

\begin{tabular}{lcc} 
& $\begin{array}{c}\text { Thymus antigen } \\
P \text { value }\end{array}$ & $\begin{array}{c}\text { LN antigen } \\
P \text { value }\end{array}$ \\
\hline MS $v$. normals & $<0.001$ & $<0.001$ \\
MS $v$. ONDt & $<0.001$ & $0.005-0.001$ \\
MS $v$. GPI & $0.6-0.5$ & $0.7-0.6$ \\
OND $v$. normals & $<0.001$ & $<0.001$ \\
OND $v$. GPI & $<0.001$ & $0.05-0.025$ \\
GPI $v$. normals & $<0.001$ & $<0.001$ \\
\hline
\end{tabular}

* lymph node.

† OND $=$ other neurological diseases excluding GPI (general paralysis of the insane). 
TABLE 3

STATISTICAL COMPARISON OF LYMPHOCYTE SENSITIZATION TO THYMUS AND LYMPH NODE ANTIGEN IN MULTIPLE SCLEROSIS, NEUROLOGICAL DISEASES, GPI, AND NORMAL SUBJECTS

\begin{tabular}{lc}
\hline & $\begin{array}{c}\text { Thymus v. } L N \\
\text { P value }\end{array}$ \\
\hline MS & $<0.001$ \\
OND & $0.05-0.025$ \\
GPI & $<0.001$ \\
Normals & $0.9-0.8$ \\
\hline
\end{tabular}

thymus-LN difference exceeded $2 \cdot 5 \%$-that is, $p<0.01$-in four of the seven acute cases and reached $P<0.025$ in the remaining three. None of the OND group showed significant individual thymus-LN difference, although as groups the difference reached $P=0 \cdot 05-0 \cdot 025$. Among the GPI cases the thymus-LN difference reached $P<0.01$ in four out of eight and another reached $P<0.025$.

\section{DISCUSSION}

The finding of raised lymphocyte sensitization to thymus was incidental to another study but has a ready explanation in the presence of the theta $(\phi)$ allo-antigen in both thymus and brain. This antigen has been found associated with thymus cells and brain in mice (Reif and Allen, 1964, 1966) and to a lesser extent with spleen and lymph nodes. While much work on the antigen common to brain and thymus has been carried out since that time, this has been almost exclusively in the mouse (Raff, 1971) and no direct evidence comes from studies in man (Thomas, 1972). The present findings suggest that there is greater sensitization to thymus in MS than in other nervous diseases in general. The exception is GPI. The explanation might be in the degree of parenchymatous destruction which is comparable in MS and neurosyphilis and greatly exceeds that in OND. The degree of thymic sensitization may thus reflect the extent of immunization which has resulted from brain destruction. On the other hand there is also in both MS and GPI gliosis of much greater degree than is met with in other neurological diseases in $\bar{z}$ general so that the special sensitization tos thymus might mean association of the $\phi$-typeen antigen with astrocytes and there is some experi $=\bar{c}$ mental evidence that this is so (Field ando Shenton, unpublished).

There was some sensitization to lymph node $\frac{\text { ? }}{\mathrm{N}}$. antigen in both MS and OND but this was significantly less than to thymus, bearing out Reif and Allen's claim that theta antigen is present in only small amounts in lymph node.

\section{REFERENCES}

Bloom, B. R., and Bennett, B. (1966). Mechanism of $a \varrho$ reaction in vitro associated with delayed-type hypersensitivity. Science, 153, 80-82.

Caspary, E. A. (1971). Lymphocyte-antigen interaction in $\vec{\circ}$ electrophoretic mobility test for cellular sensitization. $\overrightarrow{\vec{\omega}}$ Nature, New Biology, 231, 24.

Caspary, E. A. (1972). The mechanism of antigen-induced electrophoretic mobility reduction of guinea-pig macro- $\overline{3}$ phages. Clinical and Experimental Immunology, 11, 305-0 309.

Caspary, E. A., and Field, E. J. (1965). An encephalitogenic $\overparen{\Omega}$ protein of human origin; some chemical and biologict properties. Annals of the New York Academy of Sciences,
122, 182-198.

Caspary, E. A., and Field, E. J. (1971). Specific lymphocy磨 sensitization in cancer: is there a common antigen $\mathrm{f}-$ human malignant neoplasia? British Medical Journal, \& 613-617.

Coulson, A. S., and Chalmers, D. G. (1967). Response fi human blood lymphocytes to tuberculin PPD in tisste culture. Immunology, 12, 417-429.

David, J. R., Al-Askari, S., Lawrence, H. S., and Thomas, (1964). Delayed hypersensitivity in vitro. I. The specificity of inhibition of cell migration by antigens. Journal of Immunology, 93, 264-273.

Field, E. J. (1972). Delayed hypersensitivity studies: some applications of cell electrophoresis. Journal of the Royal College of Physicians of London, 6, 316-326.

Field, E. J., and Caspary, E. A. (1970). Lymphocyte sensitisation: an in vitro test for cancer? Lancet, 2, 1337-1341.

Hughes, D., and Caspary, E. A. (1970). Lymphocyte $\overline{\bar{O}}$ transformation in vitro measured by tritiated thymidine uptake. I. Lymphocyte culture techniques. International Archives of Allergy, 37, 506-531.

Raff, M. C. (1971). The use of surface antigenic markers to define different populations of lymphocytes in the mouse. In Cell Interactions and Receptor Antibodies in Immune Responses, pp. 83-90. Edited by O. Mäkelä, A. Cross, and T. U. Kosunen. Academic Press: London.

Reif, A. E., and Allen, J. M. V. (1964). The AKR thymic antigen and its distribution in leukemias and nervous tissues. Journal of Experimental Medicine, 120, 413-433.

Reif, A. E., and Allen, J. M. V. (1966). Mouse thymic isoantigens. Nature, 209, 521-523.

Thomas, D. B. (1972). Antibodies to membrane antigen(s) common to thymocytes and a subpopulation of lymphocytes in infectious-mononucleosis sera. Lancet, 1, 399-403. 